\title{
Commodity price pass-through along the pricing chain
}

\author{
Rebeca Jiménez-Rodríguez ${ }^{1}$ (1) - Amalia Morales-Zumaquero ${ }^{2}$
}

Accepted: 14 June 2021 / Published online: 3 July 2021

(C) The Author(s) 2021

\begin{abstract}
This paper analyses the commodity price pass-through along the pricing chain for the global commodity price index and the indices of its main categories (i.e., agricultural raw materials, food and beverages, energy and metals) in the world, advanced and emerging economies. To do so, the study considers country-by-country vector autoregression models and pool the results by taking weighted means for 18 advanced economies and 19 emerging countries, as well as for the world (defined as the sum of advanced and emerging economies). The results show the following: (i) there is evidence in favour of partial pass-through from commodity prices to producer prices, although the evidence for the pass-through to consumer prices is less evident; (ii) the pass-through in the world seems to be led by both advanced and emerging countries for producer prices and only by advanced economies for consumer prices; (iii) higher prices in the four categories (agricultural raw materials only in the short-run) induce significant higher producer prices in almost all cases, with shocks in the prices of energy and metals showing the largest effects; and (iv) energy prices explain the highest variability of producer and consumer prices.
\end{abstract}

Keywords Commodity price pass-through $\cdot$ Producer prices $\cdot$ Consumer prices

JEL Classifications E31 $\cdot$ C32

Rebeca Jiménez-Rodríguez

rebeca.jimenez@usal.es

Amalia Morales-Zumaquero

amalia@uma.es

1 Department of Economics, University of Salamanca, Campus Miguel de Unamuno, 37007 Salamanca, Spain

2 Department of Economics, University of Málaga, Campus El Ejido, 29071 Málaga, Spain 


\section{Introduction}

In the mid-2000s, commodity prices (specially, food and energy prices) experienced a sharp increase driving inflation up worldwide. This fact renewed the interest in studying the relation between commodity prices and inflation. It has been well established in the literature that commodity prices could affect inflation through the first-round effects, either the direct effects on consumers (e.g., more expensive energy bills) or the indirect ones on producers (e.g., higher production costs due to higher energy costs), and the second-round effects related to consumer and producer expectations that may impact negatively on consumption and investment (Castro et al., 2017; ECB, 2010).

The related literature has highlighted different reasons why it may be relevant to analyse the relation between commodity prices and producer/consumer prices. Among them, we can point out the following: (i) monetary authorities may use commodity prices as leading indicators of inflation (Ciner, 2011; Mossa, 1998) and so anticipate their monetary policies to counteract the negative impact that changes in commodity prices may have on the economy; (ii) higher commodity prices lead to higher production costs (Garner, 1989; Marquis \& Cunningham, 1990), which may cause higher consumer prices if producers do not absorb totally these changes in the costs and may also reduce investment of firms due to these higher costs; (iii) higher commodity prices may reduce disposable income of consumers when producers transfer price pressure to consumers (FAO, 2017); and (iv) higher flexibility of commodity prices with respect to the price of other goods and services allows them to adjust quickly after suffering a shock, but the impact of such a shock on the price of other goods and services is long-lasting (Cheung, 2009), which gives rise to important consequences on real economic activity.

The previous empirical literature has mostly focused on analysing the macroeconomic effects of changes in commodity prices. The first strand of this literature has studied the impact of commodity price shocks on economic growth. Thus, commodity price changes seem to affect long-run economic growth, with commodity price volatility increasing both uncertainty and risk, and so leading to decrease investment (UNCTAD, 2012). Countries that rely heavily on a commodity that shows high price volatility have more volatile terms of trade and so less direct investment, leading to less economic growth rates (Blattman et al., 2007; UNCTAD, 2012). In particular, previous evidence shows that commodity price changes particularly affect the economic growth rates in low-income countries (Bredenkamp \& Bersch, 2012; International Monetary Fund, 2012; UNCTAD, 2012).

The second strand of the literature focuses on the effects of commodity prices on inflation. Thus, Blomberg and Harris (1995) analyse the link between commodity prices and consumer prices by considering five major U.S. commodity indices (the Commodity Research Bureau-CRB-spot index, the Journal of Commerce index, the crude Producer Price Index-PPI, the National Association of Purchasing price index and the Federal Reserve Bank of Philadelphia's 
prices paid index) and three subgroups of commodities (gold, oil, food). They obtain that there is no long-run link between the level of commodity prices and the level of consumer prices, but there is a connection between the level of commodity prices and the rate of consumer price inflation. Adams and Ichino (1995) study the effects of the prices of five primary commodity categories (agricultural raw materials, beverages, foods, metals and petroleum) on inflation in the industrial world and they obtain that increases in commodity prices have little effect on inflation unless strong shocks happen in the commodity market. Ciner (2011) analyses contemporaneous and causal linkages between commodity prices (measured as the CRB commodity futures index, which includes 19 commodities in the version 2005) and U.S. consumer inflation using domain statistical methods. His results show that there is a long-run positive relation between commodity prices and inflation. Cecchetti and Moessner (2008) and Liu and Weidner (2011) find that the second-round effects were very weak for a large number of countries and, consequently, headline inflation tended to converge to core inflation. Hobijn (2008) studies the effects of grain and oil prices on the U.S. Personal Consumption Expenditures index of inflation for the period 2006-2008 and obtains that the impact is modest. Likewise, Ajmera et al. (2012) show the modest effects that changes in the price of four commodities (crops, animal slaughter and processing, dairy, and oil and natural gas) have on the overall U.S. Consumer Price Index (CPI) inflation over the period 2003-2008. Fernández (2014) considers four U.S. price indices (CPI Urban Consumers-All items, the U.S. CPI Urban Consumer Commodities, the PPI Finished Goods and the PPI Crude Materials for Further Processing) and 31 commodity prices and she obtains that not only shocks in commodity prices can impact on aggregate price indices, but also shocks in aggregate price indices can impact on commodity prices. Chen et al. (2014) explore five small commodity-exporting countries under inflation targeting and obtain that commodity price aggregates have predictive power for their CPI and PPI inflation. Ramalhete-Moreira (2014) finds that changes in commodity prices are important for explaining consumer inflation in developed and emerging countries. Finally, Sekine and Tsuruga (2016) examine the effects of commodity prices on headline inflation by using a panel of 144 countries and find that the effects of commodity price shocks on inflation are transitory, giving support to the small role of the second-round effects on inflation.

Within the second line of the literature, we find authors who explicitly study the degree of commodity price pass-through to inflation. For example, De Gregorio et al. (2007) study the pass-through from oil prices to the general price level for 34 countries and conclude that the pass-through has fallen worldwide during the last 30 years. Chen (2009) analyses the oil price pass-through to inflation for 19 industrialized countries and obtains evidence in favour of a decline in the oil price passthrough. Rigobon (2010) analyses the pass-through from commodity prices to retail prices using micro price data for 50 countries. His results show that the response of countries to shocks is different and that sectors respond differently across countries and commodities, with sectoral characteristics explaining a third of all the explained variation. Ferrucci et al. (2012) analyse the pass-through of food commodity prices to final consumer prices in the euro area and obtain that commodity prices are the 
main determinant of the increase in CPI and PPI. Gelos and Ustyugova (2017) consider a broad range of structural characteristics and policy benchmarks in 31 advanced and 60 emerging and developing countries, and obtain that countries with higher food shares in CPI baskets, fuel intensities, and with previous high inflation levels were more susceptible to develop inflationary effects from commodity prices shocks. More recently, Comunalea and Simolab (2018) study the pass-through of nominal exchange rates and commodity prices to consumer prices in the Commonwealth of Independent States (CIS) and obtain that the pass-through of commodity prices is explicitly significant. This paper contributes to this specific strand of the literature.

It is our aim to provide new evidence on the pass-through of commodity prices to producer and consumer prices. In doing so, we study the commodity price passthrough along the pricing chain for the global commodity price index and the indices of its main categories (agricultural raw materials, food and beverages, energy and metals) in the world, advanced and emerging economies by estimating country-bycountry VAR models and pooling the results by taking weighted means for the corresponding group of countries. Notice that we use individual countries' PPI and CPI indices and country-specific commodity price indices with time-varying weights.

The contribution of this paper could be summarized in answering the next four key questions: (i) is the degree of commodity price pass-through to producer and consumer prices similar in advanced and emerging economies?; (ii) which group of countries (advanced or emerging countries) is leading the pass-through in the world?; (iii) do energy prices have the most important consequences on producer and consumer prices?; and (iv) which category of the global price index of all commodities (i.e., agricultural raw materials, food and beverages, energy and metals) exhibits higher effects?

The rest of the paper is organized as follows. Section 2 describes the data and the econometric methodology. Section 3 presents the estimation results. Finally, Sect. 4 includes the concluding remarks.

\section{Data and methodology}

\subsection{Data}

The new database from International Monetary Fund (IMF) Commodity Terms of Trade (https://data.imf.org/?sk=2CDDCCB8-0B59-43E9-B6A0-59210D5605 D2) provides a new aggregate commodity price index, which is country-specific. ${ }^{1}$ In particular, country-specific commodity price indices (including export, import, and terms-of-trade indices) are reported for different economies. ${ }^{2}$ For each country,

\footnotetext{
${ }^{1}$ Following the suggestion of a referee, we use country-specific commodity price indices instead of aggregate commodity price indices provided by the IMF Primary Commodity Prices database.

2 See Gruss and Kebhaj (2019) for technical details.
} 
Gruss and Kebhaj (2019) consider that the change in the international real price of up to 45 individual commodities (which are divided into four different categories: agricultural raw materials, food and beverages, energy and metals) ${ }^{3}$ is weighted using commodity-level trade data and they provide two variants for each index, one considering time-invariant weights and other using time-varying weights.

It is worth mentioning that the IMF Primary Commodity Terms of Trade database provides country-specific commodity price indices, but it does not provide such indices by categories. However, Bernard Gruss and Suhaib Kebhaj have graciously provided us with data of country-specific commodity price indices by categories. This has allowed us not only to analyse the commodity price pass-through along the pricing change at the aggregate level, but also at the disaggregate level.

Therefore, we consider 37 countries (18 advanced countries and 19 emerging countries; all shown in Table 1$)^{4}$ and we use the country-specific commodity export ${ }^{5}$ price index (calculated by using individual commodities weighted by the ratio of exports to total commodity exports and with time-varying weights) as the global price index of all commodities that are internationally traded. Additionally, we consider its main four categories: (i) agricultural raw materials export price index (obtained by using eight individual commodities-cotton, hard logs, hard sawnwood, hides, natural rubber, softlogs, soft sawnwood, and wool-weighted by the ratio of exports to total commodity exports and with time-varying weights) (ii) food and beverages export price index (obtained by using twenty-five individual commodities_bananas, barley, beef, cocoa, coffee, corn, fish, fish meal, groundnuts, lamb, olive oil, oranges, palm oil, poultry, rapeseed oil, rice, shrimp, soybean meal, soybean oil, soybeans, sugar, sunflower seed oil, swine meat, tea, and wheatweighted by the ratio of exports to total commodity exports and with time-varying weights); (iii) energy export price index (obtained by using three individual commodities - coal, crude oil, and natural gas - weighted by the ratio of exports to total commodity exports and with time-varying weights); and (iv) metals export price index (obtained by using nine individual commodities-aluminum, copper, gold, iron ore, lead, nickel, tin, uranium, and zinc-weighted by the ratio of exports to total commodity exports and with time-varying weights). ${ }^{6}$

Given that our aim is both to analyse how commodity price shocks are transmitted to producer and consumer prices at the global level and to compare such a passthrough in advanced countries versus the one in emerging economies, we analyse

\footnotetext{
3 See Table A2 of Gruss and Kebhaj (2019), where the list of individual commodities included in each category is provided, as well as the detailed price source for each commodity.

4 Table 1 includes the countries considered and their shares in total world gross domestic product (GDP) at purchasing power parities (PPP). Thus, the reported share for each country is the average weight of the country's GDP in the global GDP based on PPP over the longest available sample at IMF dataset (World Economic Outlook, October 2020) (https://www.imf.org/en/Publications/WEO/weo-database/ 2020/October)

${ }^{5}$ Following the related literature, we consider the commodity export price index. However, the empirical analysis developed in this paper has been also replicated for the commodity import price index. Results are highly similar and are available upon request.

${ }^{6}$ It is worth mentioning that all commodity prices used are country-specific and are calculated by using time-varying weights.
} 


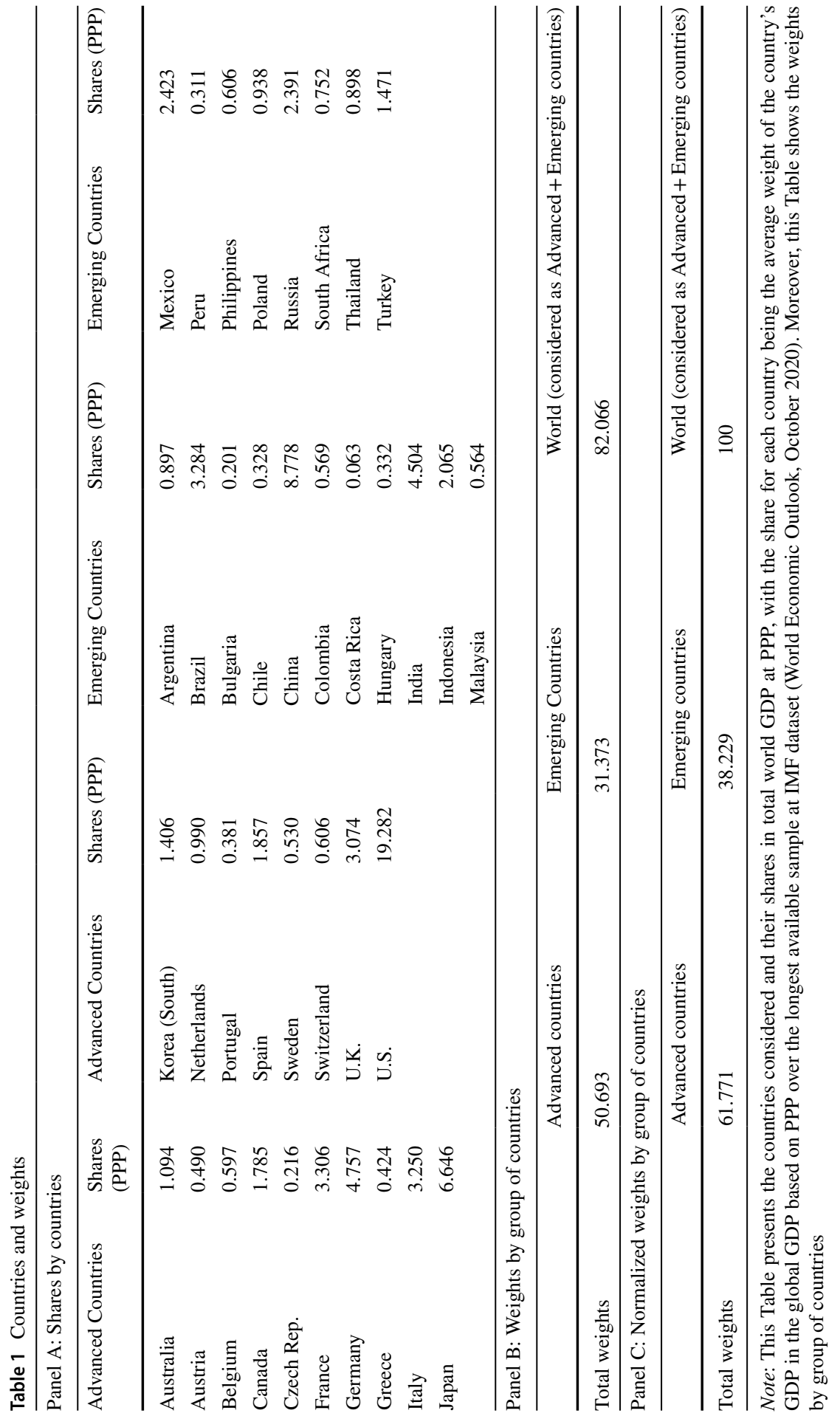


each individual country included in Table 1 by running country-by-country VAR models and pool the results by taking weighted means for advanced countries and emerging countries, as well as for the world. ${ }^{7}$ In doing so, we need to consider the producer and consumer price indices of each country. The database of Global Economic Indicators (DGEI) developed by the Federal Reserve Bank of Dallas (https:// www.dallasfed.org/institute/dgei) contains the Headline Consumer Price Index (CPI) and Producer Price Index (PPI) (or Wholesale Price Index, WPI) ${ }^{8}$ for the world (excluding the U.S.), the advanced (excluding the U.S.) countries, the U.S. and the emerging economies. ${ }^{9}$ However, this database does not provide the individual country data, but Enrique Martínez-García and his colleagues at the Federal Reserve Bank of Dallas have graciously provided us with such data. This ensures both the good quality of the data and the consistency of the way the data are calculated.

Table 2 shows the available sample of each country for the different variables considered in levels.

\subsection{Methodology}

We follow the approach used by Furlong and Ingenito (1996) and Ferrucci et al. (2012) to study the pass-through along the pricing chain by considering a VAR model. In doing so, we run country-by-country 12th-order VAR models for the global price index of all commodities and its main four categories (agricultural raw materials, food and beverages, energy and metals). We pool the results for the global price and its main categories by taking weighted means ${ }^{10}$ for advanced countries and emerging countries, as well as for the world.

The reduced-form of the VAR model may be written as:

$$
Y_{t}=c+\sum_{j=1}^{12} \Phi_{j} Y_{t-j}+\varepsilon_{t}
$$

where $Y_{t}$ is a $(3 \times 1)$ vector of endogenous variables (containing the first log-differences of the corresponding country-specific commodity price index and the first log-differences of both producer and consumer price indices), $c$ is $(3 \times 1)$ intercept vector, $\Phi_{j}$ is the $j$ th $(3 \times 3)$ matrix of autoregressive coefficients, and $\varepsilon_{t}$ is the $(3 \times 1)$ generalization of a white noise process with variance-covariance matrix $\Omega$.

\footnotetext{
7 We would like to thank a referee for suggesting to use country-by-country estimation and pool these results instead of using directly aggregate data.

${ }^{8}$ It is worth noting that the DGEI dataset mixes producer and wholesale prices. Grossman et al. (2013) state "The WPI differs from the PPI because it includes domestically produced goods sold in the home market (also included in the PPI) and imported goods (which are excluded from the PPI). WPI excludes prices of exported goods (which are included in the PPI). WPI also measures purchasers' prices-including transportation costs, sales taxes, and VAT_-while PPI measures sellers' prices at the factory.".

9 DGEI reports data that have been seasonally adjusted by X12-ARIMA method (see Grossman et al., 2013).

10 The weights used to pool the results are those included in Table 1.
} 
Table 2 Sample period

\begin{tabular}{|c|c|c|c|c|}
\hline Country & $\begin{array}{l}\text { Country-specific } \\
\text { commodity price } \\
\text { indicators }\end{array}$ & CPI & PPI/WPI & Common Sample \\
\hline Australia & 1980M1-2020M10 & 1980M1-2020M6 & 1998M7-2020M6 & 1998M7-2020M6 \\
\hline Austria & 1980M1-2020M10 & 1980M1-2020M8 & 1996M1-2020M8 & 1996M1-2020M8 \\
\hline Belgium & 1999M1-2020M10 & 1980M1-2020M8 & 1980M1-2020M8 & 1999M1-2020M8 \\
\hline Canada & 1980M1-2020M10 & 1980M1-2020M8 & 1980M1-2020M8 & 1980M1-2020M8 \\
\hline Czech Republic & 1995M1-2020M10 & 1991M1-2020M8 & 1991M2-2020M8 & 1995M1-2020M8 \\
\hline France & 1980M1-2020M10 & 1980M1-2020M9 & 1995M1-2020M8 & 1995M1-2020M8 \\
\hline Germany & 1980M1-2020M10 & 1980M1-2020M9 & 1980M1-2020M8 & 1980M1-2020M8 \\
\hline Greece & 1980M1-2020M10 & 1980M1-2020M8 & 1995M1-2020M8 & 1995M1-2020M8 \\
\hline Italy & 1980M1-2020M10 & 1980M1-2020M9 & 1981M1-2020M8 & 1981M1-2020M8 \\
\hline Japan & 80M1-2020M10 & 1980M1-2020M8 & 1980M1 & 20M8 \\
\hline Korea (South) & 1980M1-2020M10 & 1980M1-2020M8 & 1980M1-2020M8 & 1980M1-2020M8 \\
\hline Netherlands & 1980M1-2020M10 & 1980M1-2020M8 & 1981M1-2020M8 & 1981M1-2020M8 \\
\hline Portugal & 1980M1-2020M10 & 1980M1-2020M9 & 1990M1-2020M8 & 1990M1-2020M8 \\
\hline Spain & 1980M1-2020M10 & 1980M1-2020M9 & 1980M1-2020M8 & 1980M1-2020M8 \\
\hline Sweden & 1980M1-2020M10 & 1980M1-2020M8 & 1980M1-2020M8 & 1980M1-2020M8 \\
\hline Switzerland & 1980M1-2020M10 & 1980M1-2020M9 & 1980M1-2020M8 & 1980M1-2020M8 \\
\hline United Kingdom & 1980M1-2020M10 & 1980M1-2020M8 & 1980M1-2020M8 & 1980M1-2020M8 \\
\hline United States & 1980M1-2020M10 & 1980M1-2020M8 & 1980M1-2020M8 & 1980M1-2020M8 \\
\hline Argentina & 1980M1-2020M10 & 1980M1-2020M8 & 1993M1-2020M8 & 1993M1-2020M8 \\
\hline Brazil & 1980M1-2020M10 & 1980M1-2020M8 & 1991M8-2020M8 & 1991M8-2020M8 \\
\hline Bulgaria & 1980M1-2020M10 & 1990M5-2020M8 & 2004M1-2020M8 & 2004M1-2020M8 \\
\hline Chile & 1980M1-2020M10 & 1980M1-2020M8 & 2003M4-2020M8 & 2003M4-2020M8 \\
\hline China & 1980M1-2020M10 & 1980M1-2020M8 & 1996M1-2020M8 & 1996M1-2020M8 \\
\hline Colombia & 1980M1-2020M10 & 1980M1-2020M8 & 1999M6-2020M8 & 1999M6-2020M8 \\
\hline Costa Rica & 1980M1-2020M10 & 1980M1-2020M8 & 1991M1-2020M8 & 1991M1-2020M8 \\
\hline Hungary & [1-2020M10 & 1980M1-2020M8 & 1986M1-2020M8 & 1986M1-2020M8 \\
\hline India & 1980M1-2020M10 & 1980M1-2020M8 & 1980M1-2020M8 & 1980M1-2020M8 \\
\hline Indonesia & 1980M1-2020M10 & 1980M1-2020M9 & 1980M2-2019M11 & 1980M2-2019M11 \\
\hline Malaysia & 1980M1-2020M10 & 1980M1-2020M8 & 2001M1-2020M8 & 2001M1-2020M8 \\
\hline Mexico & I1-2020M10 & 1980M1-2020M8 & 2003M12-2020M8 & 2003M12-2020M8 \\
\hline Peru & 1980M1-2020M10 & 1980M1-2020M9 & 1986M1-2020M8 & 1986M1-2020M8 \\
\hline pines & 80M1-2020M10 & M8 & 198 & $20 \mathrm{M} 8$ \\
\hline Poland & 1980M1-2020M10 & 1982M1-2020M8 & 1985M6-2020M8 & 1985M6-2020M8 \\
\hline Russia & 1992M1-2020M10 & 1990M12-2020M8 & 1997M12-2020M8 & 1997M12-202 \\
\hline South Africa & 1980M1-2020M10 & 1980M1-2020M8 & 1980M1-2020M8 & 1980M1-2020M8 \\
\hline Thailand & 1980M1-2020M10 & 1980M1-2020M8 & 1995M1-2020M8 & 1995M1-2020M8 \\
\hline Turkey & 1980M1-2020M10 & 1980M1-2020M8 & 1986M1-2020M8 & 1986M1-2020M8 \\
\hline
\end{tabular}

Note: This Table shows the available sample period for each variable in levels and each country, as well as the common sample for each particular country 
We identify the model by means of the Cholesky decomposition, which is equivalent to using exclusion restrictions on the contemporary impact of structural shocks (i.e., variables that come before in the order affect the following variables both contemporaneously and with lags, while variables that come after only affect the previous variables with lags). We consider an order of the variables consistent with the pricing chain assumption (i.e., commodity price, producer price and consumer price). ${ }^{11}$ Thus, it is assumed that changes in commodity prices have an immediate impact on producer and consumer prices, but commodity prices are contemporaneously exogenous considering that they can start to be influenced by shocks in producer and consumer prices with a delay of a month, which is not excessively restrictive. $^{12}$

We calculate the impulse responses of producer and consumer prices to a $1 \%$ shock in the corresponding commodity price and their corresponding $95 \%$ confidence bands by means of Monte Carlo with 20,000 simulations. Moreover, we obtain the forecast error variance decomposition of producer and consumer prices.

As was mentioned, the country-by-country results (available upon request) have been pooled taking weighted means for advanced and emerging countries, as well as for the world. We establish that a response is statistically significant in the pooled results when it is for at least $50 \%$ of the weighted responses in each group of countries considered.

\section{Empirical results}

This section reports both the commodity price pass-through along the pricing chain (which is measured as the cumulated impulse response of producer and consumer prices to a $1 \%$ increase in the corresponding commodity price) and the percentage of the unanticipated changes of producer and consumer prices attributed to the corresponding commodity price shock at different time horizons. Thus, Table 3 displays the estimated commodity price pass-through to producer and consumer prices for the global price index and the indices of its main categories in the world, advanced and emerging economies, while Table 4 shows the fraction of the estimated forecast error variance attributed to the corresponding commodity price shock in each group of countries studied.

Higher global price of all commodities leads to significantly higher producer prices in the world and in both advanced and emerging countries, with the passthrough not being complete. In particular, we observed that the short-run impact (i.e., the impact 3 months after the shock) of a $1 \%$ increase in the global price of all commodities on producer prices is around $0.15 \%$ for all groups of countries

\footnotetext{
11 As a robustness check, we also consider generalized impulse response functions, which provide useful information on how commodity price shocks affect domestic prices without establishing any prior about the ordering of the variables. The results (available upon request) are basically the same.

12 For instance, Lee and Ni (2002) assume that oil prices are not contemporaneously influenced by other U.S. macroeconomic variables. Likewise, Hahn (2003) considers this assumption for the euro area as a whole.
} 
Table 3 Commodity Price Pass-through to PPI and CPI

\begin{tabular}{|c|c|c|c|c|c|c|c|}
\hline & & & & & & & \\
\hline & & \multirow{2}{*}{$\begin{array}{l}\text { Global } \\
\text { Categories } \\
\end{array}$} & All conmoditic & \multirow[b]{2}{*}{ Agricultural raw materials } & \multirow[b]{2}{*}{ Food and beverages } & \multirow[b]{2}{*}{ Energy } & \multirow[b]{2}{*}{ Metals } \\
\hline & & & & & & & \\
\hline & & & & & World & & \\
\hline \multirow[t]{8}{*}{ PPI } & Contemporancous & & 0.0562 & 0.0265 & 0.0192 & 0.0297 & 0.0272 \\
\hline & After 3 months & & 0.1611 & 0.0626 & 0.1003 & 0.0824 & 0.1025 \\
\hline & After 6 months & & 0.1711 & 0.0735 & 0.1090 & 0.0784 & 0.1331 \\
\hline & After 12 months & & 0.1790 & 0.1025 & 0.1132 & 0.0773 & 0.1383 \\
\hline & $\begin{array}{l}\text { Aater } 12 \text { months } \\
\text { After } 18 \text { months }\end{array}$ & & $\begin{array}{l}0.1790 \\
0.1492\end{array}$ & $\begin{array}{l}0.1023 \\
0.1285\end{array}$ & $\begin{array}{l}0.1132 \\
0.0909\end{array}$ & $\begin{array}{l}0.0773 \\
0.0585\end{array}$ & $\begin{array}{l}0.1383 \\
0.1349\end{array}$ \\
\hline & $\begin{array}{l}\text { Atter } 18 \text { months } \\
\text { After } 24 \text { months }\end{array}$ & & $\begin{array}{l}0.1492 \\
0.1331\end{array}$ & 0.1452 & $\begin{array}{l}0.09079 \\
0.0765\end{array}$ & $\begin{array}{l}0.0 .083 \\
0.0519\end{array}$ & $\begin{array}{l}0.1349 \\
0.1236\end{array}$ \\
\hline & After 36 months & & $\begin{array}{l}0.1239 \\
0.1239\end{array}$ & 0.1619 & 0.06042 & 0.0483 & 0.1170 \\
\hline & After 60 months & & 0.1188 & 0.1794 & 0.0570 & $\begin{array}{l}0.0449 \\
0\end{array}$ & 0.1173 \\
\hline \multirow[t]{9}{*}{ CPI } & Contemporanceus & & 0.0137 & 00050 & 0,0055 & 0.0078 & 0,0074 \\
\hline & $\begin{array}{l}\text { Contemporancous } \\
\text { After } 3 \text { months }\end{array}$ & & $\begin{array}{l}0.001376 \\
0.0416\end{array}$ & $\begin{array}{l}0.0039 \\
0.0172\end{array}$ & $\begin{array}{l}0.0033 \\
0.0208\end{array}$ & $\begin{array}{l}0.0078 \\
0.0199\end{array}$ & 0.0246 \\
\hline & After 6 months & & 0.0420 & 0.0240 & 0.0218 & 0.0148 & 0.0318 \\
\hline & $\begin{array}{l}\text { Anter o months } \\
\text { After } 12 \text { months }\end{array}$ & & $\begin{array}{l}0.0420 \\
0.0365\end{array}$ & $\begin{array}{l}0.03848 \\
0.0383\end{array}$ & $\begin{array}{l}0.0718 \\
0.0178\end{array}$ & $\begin{array}{l}0.00148 \\
0.088\end{array}$ & $\begin{array}{l}0.0318 \\
0.0294\end{array}$ \\
\hline & After 18 months & & $\begin{array}{l}0.0563 \\
0.0238\end{array}$ & 0.07038 & $\begin{array}{l}0.0718 \\
-0.0026\end{array}$ & $\begin{array}{l}0.0088 \\
0.0003\end{array}$ & $\begin{array}{l}0.02845 \\
0.0285\end{array}$ \\
\hline & $\begin{array}{l}\text { After } 18 \text { months } \\
\text { After } 24 \text { months }\end{array}$ & & $\begin{array}{l}0.0238 \\
0.0144\end{array}$ & 0.0878 & $\begin{array}{l}-0.026 \\
-0.0139 \\
-0.00\end{array}$ & $\begin{array}{r}0.0003 \\
-0.0039\end{array}$ & 0.0239 \\
\hline & $\begin{array}{l}\text { After } 36 \text { months } \\
\text { fither }\end{array}$ & & 0.0065 & 0.1064 & $\begin{array}{l}-0.0239 \\
-0.0254\end{array}$ & $\begin{array}{l}-0.00089 \\
-0.0083\end{array}$ & 0.0188 \\
\hline & After 60 months & & 0.0031 & 0.1249 & $\begin{array}{l}-0.03327 \\
-0.0327\end{array}$ & $\begin{array}{l}-0.01090 \\
-0.009\end{array}$ & 0.0180 \\
\hline & & & \multicolumn{5}{|c|}{ Advanced economies } \\
\hline \multirow[t]{8}{*}{ PPI } & Contemporancous & & 0.0618 & 0.0229 & 0.0185 & 0.0332 & 0.0267 \\
\hline & After 3 months & & 0.1637 & 0.0468 & 0.0653 & 0.0853 & 0.0884 \\
\hline & $\begin{array}{l}\text { Aater mononis } \\
\text { After } 6 \text { months }\end{array}$ & & $\begin{array}{l}0.1637 \\
0.1835\end{array}$ & $\begin{array}{l}0.00548 \\
0.0540\end{array}$ & $\begin{array}{l}0.00328 \\
0.0828\end{array}$ & $\begin{array}{l}0.0033 \\
0.0920\end{array}$ & $\begin{array}{l}0.0884 \\
0.1200\end{array}$ \\
\hline & $\begin{array}{l}\text { Anter o monins } \\
\text { After } 12 \text { months }\end{array}$ & & $\begin{array}{l}0.1835 \\
0.2093\end{array}$ & $\begin{array}{l}0.0540 \\
0.0679\end{array}$ & $\begin{array}{l}0.1028 \\
0.1028\end{array}$ & $\begin{array}{l}0.0 .020 \\
0.1044\end{array}$ & $\begin{array}{l}0.1200 \\
0.1307\end{array}$ \\
\hline & $\begin{array}{l}\text { Aiter } 12 \text { monins } \\
\text { After } 18 \text { months }\end{array}$ & & $\begin{array}{l}0.20934 \\
0.1954\end{array}$ & 0.0675 & $\begin{array}{l}0.1028 \\
0.1010\end{array}$ & $\begin{array}{l}0.1044 \\
0.0950\end{array}$ & $\begin{array}{l}0.1505 \\
0.1255\end{array}$ \\
\hline & After 24 months & & 0.1865 & 0.0627 & 0.0948 & 0.0912 & 0.1219 \\
\hline & After 36 months & & 0.1899 & 0.0613 & 0.0933 & 0.0939 & 0.1213 \\
\hline & After 60 months & & 0.1934 & 0.0619 & 0.0934 & 0.0953 & 0.1253 \\
\hline \multirow[t]{9}{*}{ CPI } & Contemporaneous & & 0.0181 & 0.0068 & 0,0049 & 0.0105 & 0.0089 \\
\hline & $\begin{array}{l}\text { Afterer } 3 \text { mornonths } \\
\text { Ans }\end{array}$ & & $\begin{array}{l}0.0181 \\
0.0567\end{array}$ & 0.00153 & 0.0230 & $\begin{array}{l}0.00103 \\
0.0306\end{array}$ & $\begin{array}{l}0.0025 \\
0.0256\end{array}$ \\
\hline & After 6 months & & 0.0621 & 0.0196 & 0.0293 & 0.0319 & 0.0348 \\
\hline & After 12 months & & 0.0694 & 0.0206 & 0.0295 & 0.0373 & 0.0331 \\
\hline & After 18 months & & 0.0743 & 0.0236 & 0.0315 & $\begin{array}{l}0.0375 \\
0.0375\end{array}$ & 0.0347 \\
\hline & After 24 months & & 0 & 0.0230 & 0.0302 & 0.0384 & 0.0353 \\
\hline & After 36 months & & 0.0815 & 0.0226 & 0.0299 & $\begin{array}{l}0.0409 \\
0.0409\end{array}$ & 0.0359 \\
\hline & $\begin{array}{l}\text { After } 60 \text { months } \\
\text { and }\end{array}$ & & 0.0876 & 0.0232 & 0.0298 & 0.0435 & 0.0386 \\
\hline & & & \multicolumn{5}{|c|}{ Emerging economies } \\
\hline \multirow{8}{*}{ PPI } & Contemporaneous & & 0.0471 & 0.0325 & 0.0204 & 0.0242 & 0.0281 \\
\hline & After 3 months & & 0.1568 & 0.0883 & 0.1568 & $\begin{array}{l}0.0242 \\
0.0776\end{array}$ & 0.1253 \\
\hline & After 6 months & & 0.1512 & 0.1051 & 0.1512 & 0.0566 & 0.1542 \\
\hline & After 12 months & & & 0.1584 & 0.1301 & 0.0335 & 0.1504 \\
\hline & After 18 months & & 0.0747 & 0.2270 & 0.0747 & -0.0006 & 0.1500 \\
\hline & After 24 months & & 0.0468 & 0.2784 & 0.0468 & -0.0116 & 0.1264 \\
\hline & After 36 months & & 0.0172 & 0.3243 & 0.0172 & -0.0255 & 0.1100 \\
\hline & After 60 months & & $-0,0018$ & 0.3692 & -0.0018 & -0.0364 & 0.1044 \\
\hline \multirow[t]{8}{*}{ CPI } & Contemporancous & & 0.0066 & 0.0045 & 0.0066 & 0.0033 & 0,0048 \\
\hline & $\begin{array}{l}\text { Contemporancous } \\
\text { After } 3 \text { months }\end{array}$ & & 0.0173 & 0.0204 & 0.0173 & 0.0027 & 0.0230 \\
\hline & After 6 months & & 0.0096 & 0.0310 & 0.0096 & -0.0128 & 0.0270 \\
\hline & After 12 months & & -0.0168 & 0.0669 & -0.0168 & -0.0371 & 0.0234 \\
\hline & After 18 months & & -0.0577 & 0.1456 & -0.0577 & -0.0598 & 0.0185 \\
\hline & After 24 months & & -0.0851 & 0.1926 & -0.0851 & -0.0723 & 0.0055 \\
\hline & After 36 months & & -0.1146 & 0.2417 & -0.1146 & -0.0879 & -0.0089 \\
\hline & $\begin{array}{l}\text { Arter } r 6 \text { months } \\
\text { After } 60 \text { months }\end{array}$ & & $\begin{array}{l}-0.1746 \\
-0.1336\end{array}$ & 0.2894 & $\begin{array}{l}-0.7460 \\
-0.1336\end{array}$ & $\begin{array}{l}-0.07898 \\
-0.0988\end{array}$ & $\begin{array}{l}-0.0189 \\
-0.0152\end{array}$ \\
\hline
\end{tabular}

Note: This Table presents the commodity price pass-through to PPI/CPI, which is measured as the cumulated impulse response of PPI/CPI to a $1 \%$ increase in commodity prices. A blue slanted number means lack of significance (i.e., the cumulated response is not statistically significant at the $5 \%$ significance level)

(i.e., the world, advanced and emerging economies). The cumulated effects in the mid-run (i.e., the impact 12 months after the shock) are around $0.18 \%$ in the world and advanced countries and about $0.13 \%$ in emerging countries. After one year, the impact gradually diminishes over time, even being statistically insignificant 60 months after the shock in emerging economies. Furthermore, whilst consumer prices also increase significantly after a hike in the global price, there is no statistically significant impact on consumer prices in the emerging countries. Therefore, there seems that producers do not transmit the price pressures to consumers in emerging economies and they do only partially ${ }^{13}$ in advanced economies and in

\footnotetext{
13 It is considered that there is a complete pass-through from producer prices to consumer prices after a shock in commodity prices when the effect of such a shock on producer prices is almost equal to the one on consumer prices.
} 
Table 4 Variance decomposition

\begin{tabular}{|c|c|c|c|c|c|c|c|}
\hline & & \multirow{2}{*}{$\begin{array}{l}\text { Global } \\
\text { Categories }\end{array}$} & \multicolumn{5}{|c|}{ All commodities } \\
\hline & & & & $\begin{array}{l}\text { Agricultural } \\
\text { raw materials }\end{array}$ & $\begin{array}{l}\text { Food and bever- } \\
\text { ages }\end{array}$ & Energy & Metals \\
\hline \multicolumn{8}{|c|}{ World } \\
\hline \multirow[t]{7}{*}{ PPI } & 3-period horizon & & 30.9274 & 4.9838 & 5.1277 & 32.3369 & 11.9353 \\
\hline & 6-period horizon & & 31.5721 & 5.7213 & 5.9022 & 32.7451 & 14.6839 \\
\hline & $\begin{array}{c}\text { 12-period } \\
\text { horizon }\end{array}$ & & 31.4963 & 6.5685 & 7.7604 & 32.6456 & 15.4744 \\
\hline & $\begin{array}{r}\text { 18-period } \\
\text { horizon }\end{array}$ & & 31.3263 & 6.8662 & 7.9314 & 32.7542 & 15.4721 \\
\hline & $\begin{array}{r}\text { 24-period } \\
\text { horizon }\end{array}$ & & 31.2771 & 6.9498 & 7.9860 & 32.7169 & 15.4752 \\
\hline & $\begin{array}{r}\text { 36-period } \\
\text { horizon }\end{array}$ & & 31.2359 & 6.9645 & 8.0100 & 32.6936 & 15.4999 \\
\hline & $\begin{array}{r}60 \text {-period } \\
\text { horizon }\end{array}$ & & 31.2016 & 6.9618 & 8.0092 & 32.6598 & 15.4911 \\
\hline \multirow[t]{7}{*}{ CPI } & 3-period horizon & & 14.9586 & 2.2814 & 3.1444 & 18.8589 & 4.5327 \\
\hline & 6-period horizon & & 15.3831 & 2.8131 & 3.8638 & 19.3216 & 5.6311 \\
\hline & $\begin{array}{r}\text { 12-period } \\
\text { horizon }\end{array}$ & & 15.5634 & 3.7701 & 5.0470 & 19.7426 & 6.5425 \\
\hline & $\begin{array}{r}\text { 18-period } \\
\text { horizon }\end{array}$ & & 15.6693 & 4.1340 & 5.2822 & 20.0115 & 6.9078 \\
\hline & $\begin{array}{r}24-\text { period } \\
\text { horizon }\end{array}$ & & 15.6337 & 4.2013 & 5.3382 & 19.9733 & 7.0032 \\
\hline & $\begin{array}{l}\text { 36-period } \\
\text { horizon }\end{array}$ & & 15.5896 & 4.2207 & 5.3624 & 19.9237 & 7.0290 \\
\hline & $\begin{array}{r}\text { 60-period } \\
\text { horizon }\end{array}$ & & 15.5552 & 4.2202 & 5.3583 & 19.8868 & 7.0286 \\
\hline \multicolumn{8}{|c|}{ Advanced economies } \\
\hline \multirow[t]{7}{*}{ PPI } & 3-period horizon & & 35.1372 & 3.7437 & 5.1303 & 39.7721 & 10.0007 \\
\hline & 6-period horizon & & 36.5216 & 4.4964 & 5.9506 & 40.7694 & 13.0670 \\
\hline & $\begin{array}{r}\text { 12-period } \\
\text { horizon }\end{array}$ & & 36.6644 & 5.1472 & 8.2057 & 40.7531 & 14.1545 \\
\hline & $\begin{array}{r}\text { 18-period } \\
\text { horizon }\end{array}$ & & 36.4054 & 5.3790 & 8.3334 & 40.6044 & 14.1648 \\
\hline & $\begin{array}{r}24-\text { period } \\
\text { horizon }\end{array}$ & & 36.3181 & 5.4059 & 8.3968 & 40.5100 & 14.2033 \\
\hline & $\begin{array}{r}\text { 36-period } \\
\text { horizon }\end{array}$ & & 36.2658 & 5.4201 & 8.4167 & 40.4546 & 14.2239 \\
\hline & $\begin{array}{r}60 \text {-period } \\
\text { horizon }\end{array}$ & & 36.2148 & 5.4178 & 8.4137 & 40.4014 & 14.2168 \\
\hline \multirow[t]{5}{*}{ CPI } & 3-period horizon & & 21.1358 & 2.4387 & 3.9843 & 26.8982 & 4.8540 \\
\hline & 6-period horizon & & 21.7051 & 2.9523 & 4.8075 & 27.4046 & 5.9765 \\
\hline & $\begin{array}{r}\text { 12-period } \\
\text { horizon }\end{array}$ & & 21.4429 & 3.7411 & 6.0491 & 26.9788 & 7.0756 \\
\hline & $\begin{array}{r}\text { 18-period } \\
\text { horizon }\end{array}$ & & 21.3166 & 3.9873 & 6.2024 & 26.9336 & 7.3199 \\
\hline & $\begin{array}{r}\text { 24-period } \\
\text { horizon }\end{array}$ & & 21.1819 & 4.0297 & 6.2601 & 26.7772 & 7.3779 \\
\hline
\end{tabular}


Table 4 (continued)

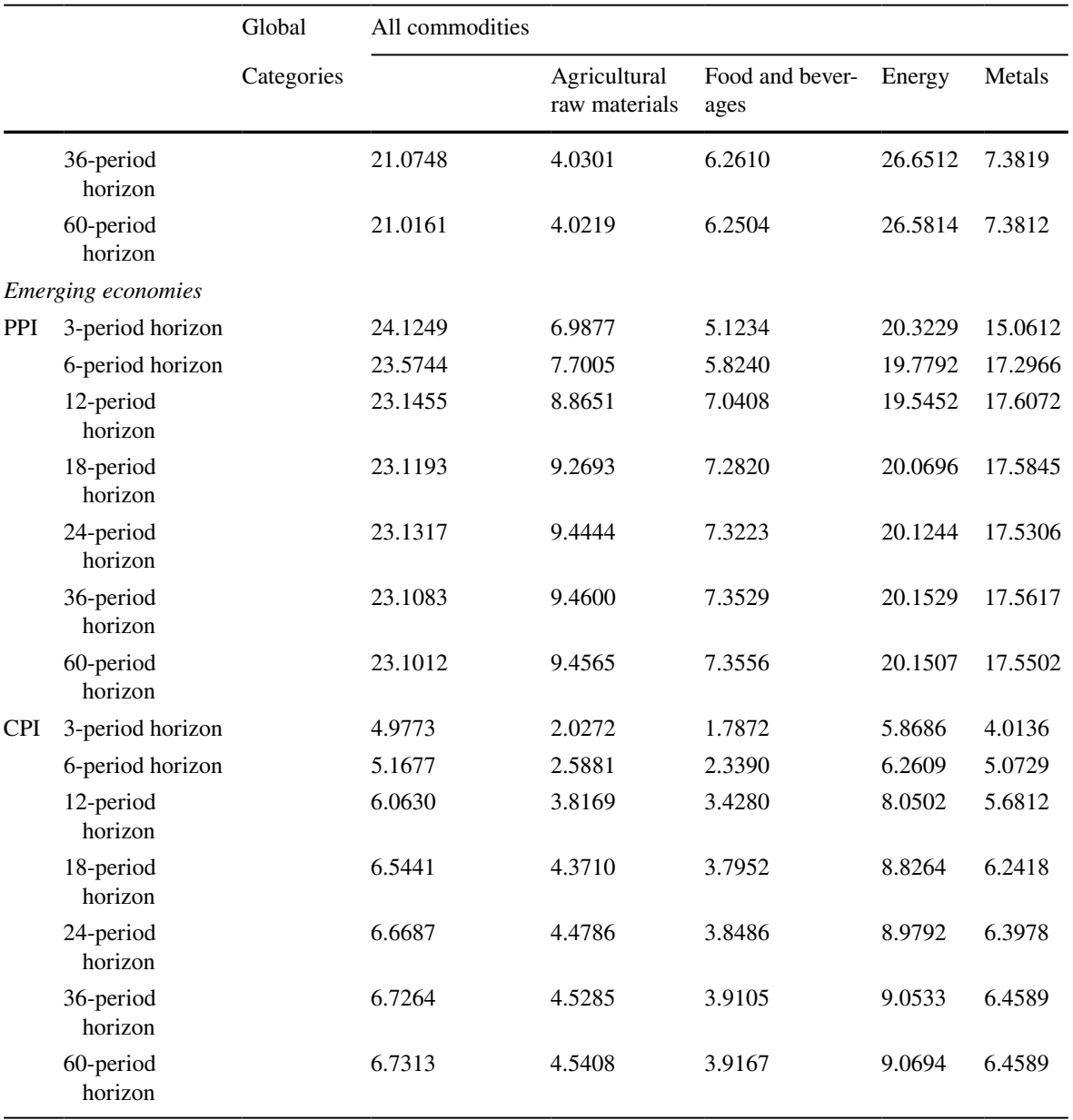

Note: This Table presents the estimated forecast error variance decomposition for PPI and CPI at different time horizons. The entries refer to the fraction of each variable's variance attributed to commodity price shocks

the world. This suggests a certain degree of adaptability of producers to assume increases in the production costs.

The variance decomposition suggests that the shock in the global price of all commodities is an important source of volatility for producer and consumer prices mostly in the world and advanced countries. The contribution of such a shock to the variability of producer prices is more than $30 \%$ for the world and advanced economies, while the contribution to consumer prices is about $15 \%$ for the world and about $20 \%$ for advanced economies. Moreover, these shocks contribute more than $20 \%$ to the volatility of producer prices and around $6 \%$ to the volatility of consumer 
prices in emerging economies. This latter result was expected given that the consumer prices do not seem to react to changes in the global price of all commodities.

When we look at the pass-through along the price chain for the price of agricultural raw materials, we observe that the impact of a shock in this price is only statistically significant in the short-run for the producer prices in all groups of countries. However, a non-statistically significant impact is found for consumer prices at any time horizon (with the exception of the contemporaneous impact in advanced countries).

The results for the variance decomposition suggest that the fraction of the variance of producer and consumer prices attributed to shocks in the price of agricultural raw materials is low, being less than $10 \%$ for all groups of countries.

The estimated pass-through for the price of food and beverages reveals that there is some evidence of reactions of producer prices, mostly in the mid-run, for the world, advanced and emerging economies. However, the reactions of consumer prices to changes in the price of food and beverages are basically not significant for any group of countries.

The results for the variance decomposition indicate that shocks in the price of food and beverages explain less than the $9 \%$ of the producer price variability and less than the $7 \%$ of the consumer price for all groups of countries.

Looking at the pass-through of energy prices to producer and consumer prices, we observe that it is statistically significant in practically all time horizons in all groups of countries, with the only exception being the consumer prices in emerging economies, where no significance is found after the contemporaneous impact. In particular, the impact of shocks in energy prices on producer prices in the mid-run (i.e., after 1 year) is around $0.08 \%, 0.10 \%$ and $0.03 \%$ in the world, advanced and emerging countries, respectively, with the impact on consumer prices being much smaller in all cases.

The results for the variance decomposition indicate that shocks in energy prices are an important source of fluctuations in producer and consumer prices in the world and advanced economies, with such shocks accounting for more than $30 \%$ of the variation of producer prices and more than $20 \%$ of the variation of consumer prices. Moreover, these shocks explain around $20 \%$ of producer prices and only about $8 \%$ of consumer prices in emerging economies.

Finally, the reaction of producer prices to a shock in the price of metals is statistically significant in all time horizons for the world and advanced economies and in the contemporaneous and mid-run horizons for emerging economies. The magnitude of the impact is larger than the one for energy prices. Moreover, a significant reaction in consumer prices is detected in the short-run for the world and advanced economies, but not for emerging economies.

The variance decomposition analysis shows that shocks in the price of metals explain around $15 \%$ of the producer price variability in all groups of countries and around $7 \%$ of consumer price variability. 
In sum, the previous empirical results reveal some general empirical regularities. First, we show evidence in favour of partial pass-through from commodity prices to producer prices, although the evidence for the pass-through to consumer prices is less evident. There seems that producers do not transmit the price pressures to consumers in emerging economies, although they do so partially in advanced economies and in the world essentially for the energy category. This suggests a certain degree of adaptability of producers to assume increases in the production costs, which is in line with Adams and Ichino (1995) who state that increases in commodity prices would have little inflationary effect unless serious commodity market shocks occurred. Second, we find a positive and statistically significant link between commodity prices and producer prices for the global price of all commodities and its categories $^{14}$ in the world, advanced and emerging economies. This result is in line with Garner (1989) and Marquis and Cunningham (1990), who argue that higher commodity prices lead to higher production costs. Third, we find mostly a positive significant link between consumer prices and the global price of all commodities, energy prices and metals price (but only in the short-run) for the world and advanced economies, but the lack of significant connection between them in emerging countries. The finding for the world and advanced countries is in line with Ciner (2011), who shows that monetary authorities could use commodity prices in policy decisions as a guide for future inflation, and Mossa (1998), who states that monetary authorities may use commodity prices as a leading indicator of inflation.

\section{Concluding remarks}

In this paper, we have found new evidence on the pass-through of commodity prices to producer and consumer prices. In particular, we have studied the commodity price pass-through along the pricing chain for the global commodity price index and the indices of its main categories (agricultural raw materials, food and beverages, energy and metals) in advanced and emerging economies and worldwide.

The empirical regularities found in this paper allow us to reply to the four key questions highlighted in the Introduction. Regarding the first question, the degree of pass-through from commodity prices to producer and consumer prices is partial in all cases (the world, advanced and emerging economies). Such a degree is highly similar in the world, advanced and emerging economies for producer prices. Instead, the significant pass-through for consumer prices seems to be essentially due to the energy category in the world and advanced economies, but this pass-through does not seem to be significant in emerging economies. ${ }^{15}$ There are different possible reasons why commodity prices do not significantly affect consumer prices in emerging economies:

\footnotetext{
14 In the case of the price of agricultural raw materials, it is only found in the short-run.

15 Notice that authors such as Fernández et al. (2017), Drechsel and Tenreyro (2018) and Fernández et al. (2018) show that commodities significantly explain output variance in emerging countries.
} 
a. Emerging economies have undergone a substantial stabilization of inflation in recent decades due to changes in the role played by emerging economies in global trade. In particular, their participation in international trade due to globalization may have induced their producers to try to increase their competitiveness at the global level keeping unaltered final sale prices despite the increase in commodity prices, which would also entail that prices at the local level are not altered and maintain inflation relatively stable.

b. Emerging economies have experienced changes in the monetary policy strategy followed by their central banks, with monetary policies being more credible.

c. Emerging economies exhibit more price rigidity due to regulation ${ }^{16}$ than advanced economies.

With respect to the second question, the pass-through in the world seems to be led by both advanced and emerging countries for the producer prices and only by advanced economies for the consumer prices via the energy category.

Regarding the third question, we find that changes in energy prices have important consequences on producer and consumer prices in the world and advanced economies and only on producer prices in emerging economies. Moreover, the contribution of the shocks in the global commodity price to the variability of producer and consumer prices seems to be run by the contribution of shocks in energy price, followed by shocks in the price of metals. These results could be explained because energy prices are, in general, more volatile than other commodity prices and, consequently, the former explain a high percentage of producer and consumer variability.

With regard to the fourth question, results reveal that higher prices in the four categories considered induce significant higher producer prices (with agricultural raw materials only being significant in the short-run) in all groups of countries. The commodity price pass-through to consumer prices is positive and statistically significant (but less important in magnitude than that for producer prices) in the case of the world and advanced economies, while the pass-through is negligible in emerging economies. Finally, by categories, it seems that energy and metals show the most relevant pass-through to producer prices for all groups of countries, although the magnitude of this pass-through in the case of food and beverages is also important in the short- and mid-run for emerging economies.

Acknowledgements We would like to thank Bernard Gruss and Suhaib Kebhaj for providing us data for country-specific commodity price indices by categories and Enrique Martínez-García and his colleagues at the Federal Reserve Bank of Dallas for graciously sharing the data of producer and consumer prices for each individual country. Additionally, the first author acknowledges support from Junta de Castilla y León under Research Grant SA049G19.

Funding Open Access funding provided thanks to the CRUE-CSIC agreement with Springer Nature.

Open Access This article is licensed under a Creative Commons Attribution 4.0 International License, which permits use, sharing, adaptation, distribution and reproduction in any medium or format, as long as you give appropriate credit to the original author(s) and the source, provide a link to the Creative

$\overline{16}$ We would like to thank a referee for this suggestion. 
Commons licence, and indicate if changes were made. The images or other third party material in this article are included in the article's Creative Commons licence, unless indicated otherwise in a credit line to the material. If material is not included in the article's Creative Commons licence and your intended use is not permitted by statutory regulation or exceeds the permitted use, you will need to obtain permission directly from the copyright holder. To view a copy of this licence, visit http://creativecommons.org/ licenses/by/4.0/.

\section{References}

Adams, F. G., \& Ichino, Y. (1995). Commodity prices and inflation: A forward-looking price model. Journal of Policy Modeling, 17(4), 397-426

Ajmera, R., Kook, N. \& Crilley, J. (2012). Impact of commodity prices movements on CPI inflation. Monthly Labor Review, U.S. Department of Labor, Bureau of Labor Statistics, 135(4), 29-43

Blattman, C., Hwang, J., \& Williamson, J. G. (2007). Winners and losers in the commodity lottery: The impact of terms of trade growth and volatility in the periphery 1870-1939. Journal of Development Economics, 82(1), 156-179

Blomberg, S.B., \& Harris, E.S. (1995). The commodity-consumer price connection: fact or fable? FRBNY Economic Policy review, October, 21-38

Bredenkamp, H., \& Bersch, J. (2012). Commodity price volatility: Impact and policy challenges for low-income countries. In R. Arezki., C. Pattillo., M. Quintyn., \& M. Zhu. (Eds.), Commodity price volatility and inclusive growth in low-income countries. International Monetary Fund

Castro, C., Jiménez-Rodríguez, R., Poncela, P., \& Senra, E. (2017). A new look at oil price passthrough into inflation: Evidence from disaggregated European data. Economia Politica, 34, 55-82

Cecchetti, S. J., \& Moessner, R. (2008). Commodity prices and inflation dynamics. BIS Quarterly Review, December, 55-66

Chen, S. S. (2009). Oil price pass-through into inflation. Energy Economics, 31(1), 126-133

Chen, Y. C., Turnovsky, J., \& Zivot, E. (2014). Forecasting inflation using commodity price aggregates. Journal of Econometrics, 183, 117-134

Cheung, C. (2009). Are commodity prices useful leading indicators of inflation? Bank of Canada Discussion Paper 2009-5

Ciner, C. (2011). Commodity prices and inflation: Testing in the frequency domain. Research in International Business and Finance, 25, 229-237

Comunalea, M., \& Simolab, H. (2018). The pass-through to consumer prices in CIS economies: The role of exchange rates, commodities and other common factors. Research in International Business and Finance, 44, 186-217

De Gregorio, J., Landerretche, O., \& Neilson, C. (2007). Another pass-through bites the dust? Oil Prices and Inflation. Economia, 7(2), 155-196

Drechsel, T., \& Tenreyro, S. (2018). Commodity booms and bust in emerging economies. Journal of International Economics, 112, 200-2018

ECB. (2010). Energy markets and the euro area macroeconomy. ECB Occasional Paper No. 113

FAO. (2017). What did we learn from the bout of high and volatile food commodity prices (2007-2013)? FAO Commodity and trade policy research, Working Paper Series 54

Fernández, V. (2014). Linear and non-linear causality between price indices and commodity prices. Resources Policy, 41, 40-51

Fernández, A., Schmitt-Grohé, S., \& Uribe, M. (2017). World shocks, world prices, and business cycles. An empirical investigation. Journal of International Economics, 108, S2-S14

Fernández, A., González, A., \& Rodríguez, D. (2018). Sharing a ride on the commodities roller coaster: Common factors in business cycles of emerging economies. Journal of International Economics, $111,99-121$

Ferrucci, G., Jiménez-Rodríguez, R., \& Onorante, L. (2012). Food price pass-through in the euro area: Non-linearity and the role of the common agricultural policy. International Journal of Central Banking, 8(1), 179-217

Furlong, F., \& Ingenito, R. (1996). Commodity prices and inflation. Economic Review, the Federal Reserve Bank of San Francisco, 2(October), 27-47 
Garner, A. C. (1989). Commodity prices: Policy target or information variables? Journal of Money, Credit and Banking, 21, 508-514

Gelos, G., \& Ustyugova, Y. (2017). Inflation responses to commodity price shocks-How and why do countries differ? Journal of International Money and Finance, 72, 28-47

Grossman, V., Mack, A., \& Martínez-García, E. (2013). Database of Global Economic Indicators (DGEI): A methodological note. Federal Reverse Bank of Dallas, Globalization and Monetary Policy Institute, Working Paper No. 166

Gruss, B., \& Kebhaj, S. (2019). Commodity Terms of Trade: A new database. International Monetary Fund Working Paper 19/21

Hahn, E. (2003). Pass-through of external shocks to euro area inflation. ECB Working Paper Series No. 243

Hobijn, B. (2008). Commodity price movements and PCE inflation. Current Issues in Economics and Finance. Federal Reserve Bank of New York, New York

International Monetary Fund. (2012). In R. Arezki., C. Pattillo., M. Quintyn., \& M. Zhu (Eds.), Commodity price volatility and inclusive growth in low-income countries. International Monetary Fund

Lee, K., \& Ni, S. (2002). On the dynamic effects of oil price shocks: A study using industry level data. Journal of Monetary Economics, 49(4), 823-852

Liu, Z., \& Weidner, J. (2011). Does headline inflation converge to core? FRBSF Economic Letter, 201124. Federal Reserve Bank of San Francisco

Marquis, M. H., \& Cunningham, S. R. (1990). Is there a role for commodity prices in the design of monetary policy? Some empirical evidence. Southern Economic Journal, 57, 169-209

Mossa, I. A. (1998). Commodity prices a leading indicator of inflation? Journal of Policy Modeling, 20(2), 201-212

Ramalhete-Moreira, R. (2014). Commodities prices volatility, expected inflation and GDP levels: An application for a net-exporting economy. Procedia Economics and Finance, 14, 435-444

Rigobon, R. (2010). Commodity prices pass-through. Central Bank of Chile Working Paper No. 572

Sekine, A., \& Tsuruga, T. (2016). Effects of commodity price shocks on inflation: A cross-country analysis. ESRI Discussion Paper Series No. 331

UNCTAD. (2012). Excessive commodity price volatility: macroeconomic effects on growth and policy options. Contribution from the UNCTAD secretariat to the G20 Commodity Markets Working Group

Publisher's Note Springer Nature remains neutral with regard to jurisdictional claims in published maps and institutional affiliations. 